\title{
Waldemar Paruch
}

(Maria Curie-Skłodowska University in Lublin, Poland)

https:/orcid.org/0000-0002-8215-8092

E-mail: wparuch@poczta.umcs.lublin.pl; wparuch@o2.pl

\section{Between Market Principles and State Security: The Economic Order in Interwar Poland under the Authoritarian System (1926-1939)}

\author{
Między zasadami rynku a bezpieczeństwem państwa: Ład gospodarczy \\ w międzywojennej Polsce w warunkach systemu autorytarnego (1926-1939)
}

\section{ABSTRACT}

The article performs the analysis of the political views on economy that had an important impact on the concepts of economic policy in the Republic of Poland put forward by Piłsudski and Piłsudski's camp - the authoritarian camp ruling in the Republic of Poland from 1926 to 1939. The author investigates the traces and the evidence of the political thought (i.e. the source material produced by the politicians of the political party and the description of decisions they made at that time).

The scope of the interest included the property regulations that were grounded not only in the economical context, but, in particular - the political one. The political bases

\begin{tabular}{|l|l|l|l|}
\hline PUBLICATION INFO \\
\hline
\end{tabular}


for economic decisions made by Józef Piłsudski and his camp and the successors were under research. In the period of the power transfer the followers of Józef Piłsudski did not legitimise the coup using the economic perspective even though the financial situation of the country was to deteriorate. Only after the coup had succeeded was the property order formulated, including the scope and the dimension of the economic order.

Key words: authoritarianism, political thought, economy, political system

\section{INTRODUCTION}

The political views on economy that determined the economic policy pursued in the Second Republic, particularly in relation to the adopted ownership regulations, were the consequence of four variables situated in the political rather than economic context.

Firstly, the interwar Polish state envisioned by the irredentist movement (the political actor that consistently sought to achieve this goal, at least from 1908) was to be restored as the First Republic (First Commonwealth). However, the state emergent after the Great War was not the realization of this political vision. Despite far-reaching changes in the international, especially Central European, environment in 1918-1920, Józef Piłsudski and his supporters did not manage to fundamentally restructure international relations. Geopolitically, the new Poland was still located in the territory between Germany and Russia because the political community destroyed in the 18th century through the partitions of the First Republic was not rebuilt. Guided by this assessment, at least since 1923 Piłsudski forecast that a new war would break out in the region thereby endangering not only Poland's sovereignty but also her overall existence, and contributing to the restoration of Russia's imperial position. This attitude defined the economic policy pursued in the Second Republic. Political decisions, including those in the realm of ownership, would have to consistently contribute to the concentration of all resources in the event of crisis, which meant the rejection of economic experiments that would have endangered political consolidation in Poland on the one hand, and consumed budget resources on the other. The Piłsudski camp consistently emphasized that after the Great War it was time to cut down consumption by the contemporary generations and curb the uncontrolled satisfaction of social needs, and, instead, live a moderate life, work with sacrifice, build the state's economic potential, and provide social support for the insolvent and unemployed ${ }^{1}$.

1 See: Zjazd działaczy gospodarczych i społecznych zwołany przez BBWR. Warszawa, 18, 19 i 20 V 1933 r., Warszawa 1933, p. 199; J. Poniatowski, Przeciać hamulce!, 'Gazeta Narodowa' 1934, 12, p. 178; Podwójny obowiazek, ‘Gazeta Polska' 14 April 1935, 104, p. 1. 
Secondly, the Second Republic had to face the danger of revolution - at first from the East, i.e. Bolshevism, and then also from the West, where triumphed fascism. While the latter influence was only external, rejected by the most of Polish political actors, the former was well received by the Communist groups in Poland and by a significant part of the minority communities, particularly in the Eastern Borderlands (Kresy). After the May coup d'état, Poland's ruling politicians noticed the influence on the public opinion and lower classes exerted by ownership decisions taken in Soviet Russia and Nazi Germany. The interference with ownership relations, or even elimination of private ownership in the two neighboring countries, had the context of ethnicity and inhabiting the Eastern Borderlands. Therefore, it included Ukrainians, Belarusians, and Jews. Without the loyalty of national minorities, chiefly, the inhabitants of the Eastern Borderlands, the war strategy and defense capabilities of the state were an illusion. For that reason, the Polish authorities, guided by the Piłsudski camp's political thought, had to counteract revolutionary propaganda against private ownership, and make prudent decisions that, consequently, would have transformed ownership without inciting a revolution or chaos. The former measures would have made the Piłsudskites, whose opponents kept reminding them of their (the Piłsudskites') leftist and radical heritage, resemble the Bolsheviks and Nazis, the latter variant would have led to an economic collapse. The headquarters, however, had appropriate knowledge about the consequences of economic crisis based on the experience of the early 1920s and early 1930s.

Thirdly, after the May coup d'état, the main axis of political rivalry in the Second Republic was the dispute between the authoritarian camp and the democratic anti-system opposition with different ideological and conception/program orientations. The Piłsudskites, who exercised dictatorial rule between 1926 and 1939, did not have to seek the voters' support i.e. in the most highly populated social strata such as peasants and workers. The reason for this was the power of Piłsudski and that of his successors. The fact that parliamentary elections were successively held, however, was not based on democratic legitimacy but it stemmed from a coup d'état. After May 1926, electoral promises lost their importance, which is why neither the dictator nor his adherents and successors had to seek the support of the populations in towns and villages by announcing fundamental changes in ownership relations. Piłsudski absolutely rejected this model of politics, regarding it as populist, propagandistic, irresponsible, and as a symptom of the particularism of the party. The Piłsudskites agreed that only dictatorship made it possible to put the economic policy in order and eradicate pathologies in this field It must 
have occurred, however, against the will of society because democratic norms clash with economic principles, which impedes the rationalization of the economic system, economic activity and ownership relations ${ }^{2}$. Instead, the Piłsudskites decided to depoliticize society, which meant depriving many social and economic problems of political characteristics. While the attitude to ownership polarized the political area of the democratic Second Republic during 1918 to 1926, under the authoritarian rule between 1926 and 1939 it lost its significance as the main factor structuring the participants in political relations by the right-center-left criterion. The essence of the Piłsudski camp's position was presented fairly exactly by Eugeniusz Kwiatkowski: 'In economic evolution each fight, each confusion needlessly transferred from political life is a loss, and an economic loss is irretrievable ${ }^{\prime 3}$.

Fourthly, the political thought of the Piłsudski camp had two highly important developmental features: dualism in ideological activity, and a specified direction of evolving. The political thought of the Piłsudski's camp can be divided into two categories, mainly, the directive category and the non-directive one. The concepts and policy programs in the first category were personally formulated by the dictator, whereas in the other one he himself left only general guidelines. The political views on economy belonged to the second set of ideas, which meant that an almost free public debate on ownership was possible between different Piłsudskite groups. For the ownership decisions made by the governing camp, on the other hand, the most important was the evolution of conceptions and programs. In independent Poland Piłsudski severed his ties with the socialist movement as he viewed its program in the interwar period as radical and detrimental to the state, unrealistic to implement, and anachronistic with regard to the economic knowledge and international trends characteristic of the free market economy. After the May coup d'état the Commandant (as Piłsudski was often called) made a sharp turn towards the conservatives, whose important circles became part of his formation and their politicians joined the Sanacja (Sanation i.e. moral healing of the body politic) government. The intention was not only to reactivate

2 Zdarzenia i poglady, 'Gospodarka Narodowa' 1934, 3, p. 1; Jan Bobrzyński o kwestiach ustrojowych Drugiej Rzeczypospolitej, ed. E. Czapiewski, Warszawa 1998, pp. 163, 165, 186; E. Kwiatkowski, Prawo zwycięstwa: Odczyt, wygłoszony w Poznaniu 26 maja r. 1929, Warszawa 1929, p. 30.

${ }^{3}$ 'W ewolucji gospodarczej każda walka, każdy zamęt, przeniesiony zbędnie z życia politycznego, to strata, a strata gospodarcza jest niepowetowana'. E. Kwiatkowski, Tendencje $i$ postulaty rozwoju gospodarczego Polski: Referat, wygłoszony na kongresie Izb PrzemysłowoHandlowych we Lwowie w dn. 3 września 1930 r., Warszawa 1930, p. 17. 
conservatism and apply its specific ideas but to utilize this movement to fight the main enemy - the national democratic right. After Piłsudski's death, his successors led by Edward Śmigły-Rydz, faced by the prospect of a real war and the growing importance of the center-left opposition, began to adopt some projects typical of the national-democratic thought. This tendency also applied to their views on ownership.

\section{THE POLITICAL FOUNDATIONS OF ECONOMIC DECISIONS}

At the time of power takeover in the state as a result of a coup d'état the political thinking of the Piłsudski camp was characterized by three features. Firstly, Piłsudski did not justify the decision to carry out a military coup by means of economic arguments although the situation in the economy had crisis symptoms and actually facilitated the success of the coup perpetrators. The then eminent economist and Sanacja politician, Adam Krzyżanowski assessed this correctly: 'Poor fiscal management paved Marshal Piłsudski's way to success $[\ldots]^{\prime 4}$. The specific causes were pointed out by another economist, Roger Battaglia, who accused the 'pre-May 1926' democratic government of contributing to the collapse of economic reforms, of upsetting the balance between the sectors of the economy, ignoring the needs of the state and of pursuing a wrong fiscal policy ${ }^{5}$. Secondly, when taking over government in Poland, the Commandant did not have either his own economic program or a model of economic policy, or a vision of economic order. The foregoing issues did not have a priority status in his previous political activities, and his immediate associates were neither economic politicians, nor experts in this field or economic theorists ${ }^{6}$. Thirdly, Piłsudski and his associates believed that politics took precedence over management and economy, and idealist goals had priority over materialistic ones, and that the state's power prevailed over economic life ${ }^{7}$. Without judicious politics, the political will and the strong state it was impossible to pursue either effective economic policy or efficient economy.

4 'Zła gospodarka skarbowa uścieliła Marszałkowi drogę do władzy [...]'. A. Krzyżanowski, Polityka i gospodarstwo: Pisma pomniejsze oraz przemówienia 1920-1931, Kraków 1931, p. 346.

5 R. Battaglia, O programie gospodarczym Polski oraz o warunkach rozwoju poszczególnych gatęzi wytwórczości, Warszawa 1927, pp. 23-27.

6 Z. Landau, Plan stabilizacji 1927-1930: Geneza, założenia, wyniki, Warszawa 1969, pp. 14, 39; J. Rakowski, Ideologia gospodarcza epoki Józefa Piłsudskiego, 'Niepodległość' 1948, 1, pp. 119-135; M. Leczyk, Oblicze społeczno-polityczne Drugiej Rzeczypospolitej, Warszawa 1988, p. 215.

7 Polityka i ekonomia, ‘Gazeta Polska’ 29 December 1938, 356, p. 1. 
Those issues were the grounds for taking four crucial and systemic decisions by the Piłsudski camp: 1) continuation of the policy of the predecessors, which meant not only giving up revolutionary actions but also refraining from announcing their own economic program; 2) the long-term ministerial and high-ranking administrative appointments by Piłsudski of politicians who had different economic views but rejected radical thinking about the economy, which was noticeable in treasury, planning, agriculture, industries and in trade ${ }^{8}$; 3) creation in the Piłsudskite formation of favorable conditions for many policy debates between various Piłsudskite orientations, involving academic and economic circles $^{9}$; 4) the simultaneous development of dialogue and consultations with both the workers/employees and with so-called economic spheres, in the form of economic meetings and creation of consultative institutions ${ }^{10}$. The idea-building activities of the Piłsudskite camp were characterized by exceptional caution in dealing with economic issues, including ownership. Consequently, the Piłsudskite camp rejected the revolutionary variant, thereby challenging the doctrinaire and teleological attitude as well as the politicization of the problem, for the benefit of the option of cooperation with the managerial personnel, economy experts, representatives of businessmen, landowners, and employees. Support was sought for the policy of avoiding risky actions; instead, the ruling camp wanted to utilize measures tried and tested in theory and practice. It was therefore

8 See: M. Jabłonowski, Z dziejów gospodarczych Polski lat 1918-1939, Warszawa 1992, pp. 266-269.

9 Public debates between politicians, officials, and theoreticians, involving the Piłsudski camp's radicals, liberals and conservatives produced important policy documents: Na froncie gospodarczym: W dziesiąta rocznice odzyskania niepodległości. 1918. 11 XI 1928, Warszawa 1928; Zagadnienie etatyzmu w Polsce: Stenogramy przemówień wygłoszonych na zebraniu u posła Janusza Radziwiłta w dniach 12 grudnia 1928 r. i 10 stycznia 1929 r., Warszawa 1929; Pięć lat na froncie gospodarczym 1926-1931, Warszawa 1931; Archiwum Akt Nowych [hereinafter: AAN], Bezpartyjny Blok Współpracy z Rządem. Sekretariat Generalny i Klub Parlamentarny w Warszawie, ref. no. 3, pp. 71-78; Zjazd Działaczy Gospodarczych i Społecznych, 'Gazeta Polska' 20 May 1933, 138, p. 5; Uprzemystowienie Polski: Tezy Rady Naczelnej OZN uchwalone w dniach 28-29 II i 1 III 1939 r., Warszawa 1939; AAN, Obóz Zjednoczenia Narodowego. Centrala w Warszawie [hereinafter: OZN], ref. no. 26, pp. 8-11.

10 See: Materiaty odnoszace się do dziatalności Rządu w czasie od 15 maja 1926 roku do 31 grudnia 1927: Sprawozdania ministerstw, Warszawa 1928; Inwestycje, kredyty, konsumpcja, eksport, żegluga: Obrady gospodarcze w dn. 22 i 23 lutego 1928, Warszawa 1928; Narady gospodarcze Rzadu z Delegatami Izb Przemysłowo-Handlowych w dniu 7 i 8 października 1929 r., Warszawa 1929; Bieżace zagadnienia polityki gospodarczej, vol. 1, Prace Komisji Opiniodawczej (przemysłowej) przy Prezesie Komitetu Ekonomicznego Ministrów, Warszawa 1927; Bieżące zagadnienia polityki gospodarczej, vol. 4, Sprawozdanie z działalności Komisji Opiniodawczej Pracy przy Prezesie KEM za okres od dnia 17 XI 1926 r. do dnia 1 VII 1928 r., Warszawa 1928; AAN, Prezydium Rady Ministrów w Warszawie, ref. no. 491, pp. 3-9. 
emphasized that Poland was not a center of the world economy and did not impact either international economic situations or global crises but it was dependent on the world trends and had to adjust to them. This approach was most noticeable in the conditions of overcoming the Great Depression (1929-1933) and war mobilization effort (1936-1939).

The state authorities undertook three main tasks: to counteract revolution as it caused chaos and the collapse of the state; to seek an optimal economic system for Poland; and to activate the mechanism of management. Without accomplishing the last two tasks it was impossible to achieve political consolidation necessary for the implementation of Poland's own vision of the organization of Central Eastern Europe (the so-called grand idea), and to oppose the Russian and German powers, which would inevitably cause another war. The postulated ownership structure would be the means to implement priority goals. From this angle, the Piłsudskites were pragmatic and realistic politicians, which is why they had no qualms about utilizing different economic theories, sometimes mutually conflicting or exclusive to one another, on condition that they did not bear the mark of Bolshevism and Nazism. Their pragmatism manifested itself in the conviction that economy resembled politics, which is why one could not be guided in decision-making by mathematical formulas, certainty, and predictability. Economic decisionmaking would be determined by one universal criterion: the realistically identified, correctly described and diagnosed interest of the state realized in concrete historical conditions ${ }^{11}$. That attitude meant that the economic order was not a primary value in economic thinking; it should at least be assigned to achieving non-economic goals and to the interests of the Republic of Poland.

The changing historical conditions in which Poland operated fully justified the direction of evolution of the Piłsudski camp's political thought. In the first months after the May coup d'état, the guiding principle was most often the canons of neoclassical liberal economics. A view was therefore propagated (Roger Battaglia, Czesław Klarner, Ignacy Matuszewski, Józef Poniatowski) that economic life did not require a program while the development mechanism itself would have restored the necessary economic balance. That would have occurred due to the fact that there were economic laws that could not have been ignored but should have been utilized to put things in Poland in order. Economic management, it was believed, consisted in rational choices by individuals

11 Doktryna i życie, 'Gazeta Polska' 22 April 1932, 111, p. 1. 
inclined to compete and carry out production and consumption activities ${ }^{12}$. Therefore, the state could have not destroyed the foundations of running the economy. However, the neoclassical liberal economics option was majorly adjusted. Other trends in economics were then utilized, first of all the historical school and economic nationalism.

Between 1926 and 1935 the Piłsudski camp's economic thought was dominated by neoclassical liberal economics. Guided by the findings of its authors, the Piłsudskites believed that the economy should be subordinated to raison d'état, i.e. a typically political category, which, in the interwar period, meant the need to overcome Poland's economic weakness ${ }^{13}$. Eugeniusz Kwiatkowski showed four causes of that weakness; 1) too much labor force compared to available jobs, and too many jobs compared to the consumption capacity; 2) the destruction of the national wealth and capital during the war (WW1); 3) the cost of integration of the three post-Partition territories that had different economic structures; 4) cutting off of the Polish economy from its natural markets (Russian and German $)^{14}$. The overcoming of these weaknesses would be effected by creating optimal macroeconomic conditions in the state, by implementing the program of condition-dependent economic policy, and by supporting growth factors by the authorities. If the measures advocated by the followers of the historical school and economic nationalism were applied, it was motivated by the objective needs of the Polish state. When state egoism, protectionism and economic nationalism began to prevail under the conditions of overcoming the huge economic crises, then this strategy was treated as erroneous and disadvantageous to Poland. It was hoped, nevertheless, that it would be a temporary model of economic policy ${ }^{15}$.

12 R. Battaglia, O programie, pp. 14-16; C. Klarner, Drogi sanacji gospodarczej: Mowy ministra skarbu Czestawa Klarnera wygłoszone w sejmie w dniu 22 czerwca 1926 r., w senacie $w$ dniu 30 czerwca 1926 r., Warszawa 1926, pp. 21-23; Narady gospodarcze Rzadu z Delegatami Izb Przemystowo-Handlowych w dniu 7 i 8 października 1929 r., Warszawa 1929, p. 333; J. Poniatowski, Polityka gospodarcza wobec koniunktury, 'Gospodarka Narodowa' 1931, 6, pp. 85-87. See: B. Okoniewska, Gospodarka liberalna czy etatystyczna? Dyskusje o modelu gospodarczym Polski międzywojennej, ‘Dzieje Najnowsze’ 1993, 4, pp. 29-38.

13 See: A. Lityńska, Polska myśl ekonomiczna okresu międzywojennego, Kraków 1995; J. Kofman, Nacjonalizm gospodarczy - szansa czy bariera rozwoju: Przypadek Europy ŚrodkowoWschodniej w okresie międzywojennym, Warszawa 1992; M. Łapa, Modernizacja państwa: Polska polityka gospodarcza 1926-1929, Łódź 2002; U. Zagóra-Jonszta, Spory o model gospodarki Drugiej Rzeczypospolitej. (Problemy etatyzmu, planowania i kartelizacji), Katowice 1991.

14 Wytyczne programu gospodarczego rzadu: Mowa min. E. Kwiatkowskiego, wygłoszona $w$ dn. 8 b.m., 'Dzień Polski' 11 May 1930, 127, p. 3.

15 Zjazd działaczy gospodarczych i społecznych zwołany przez BBWR. Warszawa, 18, 19 i $20 \mathrm{~V}$ 1933 r., Warszawa 1933, pp. 30-34; A. Rose, Wytyczne polityki europejskich państw rolniczych po 1932 r., 'Przemysł i Handel' 2 January 1932, 1, pp. 5-7; idem, Wobec możliwości zmiany 
When the political model in question became established, an increasingly large group of the Piłsudskites was ready to adopt the rules of economic nationalism in the Republic. It was observed that the world economy destroyed unity, solidarity and freedom of exchange for protectionist attitudes. According to the publications in the Gazeta Polska, this was how Poland should behave, finding its own strategy for escaping crisis, getting ready for war, and stimulating economic situation ${ }^{16}$.

\section{THE POSTULATED OWNERSHIP ORDER}

The Piłsudskite camp regarded private ownership as the ground for the capitalist order in economy and the necessary condition for conducting economic activities and enjoying freedom. Three reasons for preferring ownership of this kind were given: it stimulated private enterprise, encouraged economic effort, and motivated for action. For these general reasons the state was expected to guard private ownership. However, the subject of discussions among the Piłsudskites was the problem of constraints imposed on this type of ownership. Before May 1926 two restrictions were pointed out: 1) the subordination of private economy to the state's industrial and trade policy; 2) the compulsory buyout of landed property for agricultural reform ${ }^{17}$. However, after the power takeover, declarations of this kind were not officially voiced, instead, it was announced that a middle-of-the road policy would be pursued regarding ownership issues. Such policy statements were made by politicians appointed by Piłsudski to run the economic affairs - Kazimierz Bartel, Czesław Klarner, Eugeniusz Kwiatkowski - in June and July 1926 when they publicly spoke on the intent to carry out a 'middle-of-the-road' policy ${ }^{18}$. The said

międzynarodowej polityki gospodarczej, 'Przemysł i Handel' 13 August 1932, 33, pp. 957-959; idem, Na progu nowego roku, 'Gazeta Polska' 5 January 1932, 5, p. 1; W.M. Zawadzki, Zagadnienia państw rolnych Europy Środkowej $i$ Wschodniej, 'Przemysł i Handel' 27 August 1932, 35, p. 1010; I. Matuszewski, Powszechna solidarność gospodarcza, 'Gazeta Polska' 28 August 1930, 236, p. 1; W. Fabierkiewicz, Wytyczne najbliższej przyszłości gospodarczej, 'Gazeta Polska' 7 November 1931, 304, p. 1; idem, Interwencjonizm państwowy, 'Gazeta Polska' 8 January 1932, 8, p. 1.

16 b.ł., Cuius regio - eius religio, 'Gazeta Polska' 29 October 1935, 300, p. 1; [Przemówienie Bogustawa Miedzińskiego w sejmowej komisji budżetowej z 8 II 1936 roku], ‘Gazeta Polska' 9 February 1936, 40, pp. 6-7; Postepy interwencjonizmu, 'Gazeta Polska' 1 August 1936, 213, p. 1.

17 Konfederacja Ludzi Pracy (Projekt), Warszawa 1924, pp. 14-15.

18 See: Z. Landau, Plan, pp. 17-29; M. Łapa, Polityka stabilizacyjna w gospodarce polskiej po przewrocie majowym (15 May - 30 September 1926 r.), 'Acta Universitatis Lodzensis. Folia Historica' 1998, 61, pp. 160-162. 
policy meant balancing between the defense of private ownership by the state against revolution directly endangering Poland's independence but also indirectly threatening it with destruction of the social order and economic system, and the imposition upon the owning classes of duties for the Republic and for the lower classes who could have threatened the raison d'état and formed the social basis for revolutionaries. The balance of this kind was regarded as beneficial to the Polish state in the existing internal historical conditions (economic weakness) and international ones (between the Bolsheviks and the Nazis).

In this way the Piłsudski camp rejected extreme solutions consisting in the dispossession of owners for the state's firm involvement in the economy, the restriction of freedom of economic entities, and the imposition of social obligations on entrepreneurs and employers. The radical-leftist and conservative-rightist approaches were thus challenged because the former threatened to destroy the economic mechanism and the economic order while the latter would have resulted in hostility or at least indifference towards the state on the part of the lower classes. Experts in economics called the Piłsudski camp's economic policy solidarism, the confrontation of contradictions, or the search for compromise ${ }^{19}$. In accordance with these messages, many decisions were made between 1926 and 1935 which actually constituted interference in ownership: the land was parceled out according to the government plan, the state sector was expanded, the state took over insolvent businesses, the banking and loan system was subordinated to the state, the state's interference in labor relations increased, and economic planning was initiated ${ }^{20}$.

Between 1935 and 1939 the Piłsudski camp began to emphasize the need to increase state interference in the use of ownership rights and in ownership relations. The new direction of activities was explicitly articulated in 1938. One of the OZN [Camp of National Unity] policy programs read 'The use of private ownership cannot be made to the detriment of the public interest ${ }^{21}$. Even firmer was the opinion expressed

19 See: R. Battaglia, Dobrobyt społeczeństwa a wychowanie, Warszawa 1932, pp. 49-50; J. Rothschild, Marshal Józef Piłsudski on State (Society Dialectics in Restored Interwar Poland, in: Poland between the Wars: 1918-1939: A collection of Papers and Discussions from the Conference "Poland between the Wars: 1918-1939" held in Bloomington, Indiana, February 21-23, 1985. A Publication of the Indiana University Polish Studies Center, Bloomington, ed. T. Wiles, Indiana 1989, p. 34; M. Nowak, T. Włudyka, Rynek kredytowy w Drugiej Rzeczypospolitej, Kraków 1992, p. 103.

${ }^{20}$ K. Dziewulski, Spór o etatyzm. Dyskusja wokót sektora państwowego w Polsce międzywojennej 1919-1939, Warszawa 1981, p. 20; W. Roszkowski, Etatyzm przemysłowy w Polsce w latach kryzysu 1929-1935, ‘Przegląd Historyczny' 1972, 1, pp. 76-77.

21 AAN, OZN, ref. no. 23, p. 49. 
by Wacław Makowski: '[...] the state can use private ownership at its own discretion; at best this will be the issue of compensation and its possible amount $^{\prime 22}$.

When analyzing the Piłsudski camp's political thought in the context of private ownership in the period between 1926 and 1939, two changes can be noticed. Firstly, from 1926 to 1935 ownership restrictions were justified by invoking raisons d'état whereas between 1935 and 1939 national justifications (or the need to weaken foreign (non-Polish) holdings) were increasingly emphasized,. Secondly, when establishing the authoritarian system between 1926 and 1935, attention focused on explaining the reasons for measures to expropriate taken by the state against private ownership. However, after the mid-1930s the state's obligations towards the national holdings were emphasized.

In the Piłsudskite political thought three ownership problems were the subject of exceptional interest of the ruling camp between 1926 and 1939: 1) parceling out of landowners' land among peasants; 2) the nationalization of private businesses, unprofitable and ruined by crises;3) the 'Polonization' of jobs for important strategic, capital or nationality reasons. Nevertheless, the Piłsudskites intended the ownership transformation in Poland to be carried out with the observance of five rules of economic management: 1) market economy influenced by the state tending towards social solidarity and respecting historical determinants; 2) the capitalist order built upon guarantees of economic freedom, respect for private ownership and profitability of economic activities; 3 ) the precedence of Poland's political raisons d'état over economic interests and social needs; 4) the indispensably strong and efficient state to ensure economic development; 5) the gradual and state-guided build-up of the foundations of modern economy.

The range and scope of the ownership transformation planned and carried out by the ruling camp in Poland between 1926 and 1939 was subordinated to the achievement of political goals, which evolved during that period. The 'middle-of-the-road' policy announced in 1926 was to stop the ownership demands by the lower classes represented by the leftist, centrist and minority parties and to significantly reduce the intensity of political dispute over these issues, which paralyzed the political arena in Poland and harmed state interests. The Piłsudski camp wanted to consolidate the whole society around the state, which is why they maintained their image of the advocates of employee groups (derived from their socialist past) but at the

22 ‘...] państwo może dysponować własnością prywatną według uznania, co najwyżej w grę wchodzić będzie kwestia odszkodowania i jego ewentualnego wymiaru'. W. Makowski, My i wy, Warszawa 1938, p. 204. 
same time they strove to neutralize the peasants - both Polish and those of national minorities - and to win over the affluent classes and the Jewish population. After 1935 the general goal changed. The evolution of the international situation, consequences of the economic crises, effects of the policy conducted in the Third Reich, Italy, and in the Soviet Union justified the treatment of economy as a political means to mobilize all socio-economic groups having Polish ethnic-cultural characteristics and constituting the national community. The point of reference was no longer Poland's multiethnic society. Ownership transformations could not therefore diminish the Polish holdings but could only lead to their extension at the expense of national minorities inhabiting both the Eastern and Western Borderlands, and in towns and in the country. The national consolidation was the goal of the middle-of-the road-policy, which is why the postulated range and scope of the state's interference in ownership relations in Poland was reconsidered and altered.

\section{THE RANGE AND SCOPE OF OWNERSHIP}

Regardless of the model of the announced and implemented economic policy, in the Piłsudski camp there was internal debate going on between the followers of neoclassical liberal economics and economic nationalism. Two groups emerged during the disputes. One was the camp's conservatives and liberals, who were opposed in the Piłsudski camp by the radicals ${ }^{23}$. Out of many subjects of controversy, the one that emerged the Polish model of economic order. While both Piłsudskite groups were against revolutionary ownership transformations, the latter opted for the development of state ownership. In the period between 1935 and 1939 political and economic processes significantly strengthened the position of the radicals in the Piłsudski camp: they began to impose their way of thinking upon the

23 For more on the two 'economic' orientations in the Piłsudski camp see: J. Faryś, Myśl gospodarcza piłsudczyków 1926-1935, 'Szczecińskie Studia Historyczne' 1987, 1, pp. 145-169; M.M. Drozdowski, O myśli politycznej piłsudczyków polemicznie, ‘Dzieje Najnowsze' 1969, 2, p. 98; idem, Stefan Starzyński prezydent Warszawy, Warszawa 1980, pp. 24-33; K. Grzybowski, Pięćdziesiąt lat 1918-1968, Kraków 1977, p. 132; J.M. Majchrowski, Silni-zwarci-gotowi: Myśl polityczna Obozu Zjednoczenia Narodowego, Warszawa 1985, pp. 88-89; J. Rakowski, op. cit., pp. 123-127; W. Nowicki, Polska myśl ekonomiczno-rolnicza w latach 1918-1939, in: Zarys polskiej myśli ekonomiczno-rolniczej do drugiej wojny światowej, ed. A. Żabko-Potopowicz, Wrocław-Warszawa-Kraków-Gdańsk 1973, pp. 328-332; T. Kowalik, Historia ekonomii w Polsce 1864-1950, Wrocław-Warszawa-Kraków 1992, pp. 151-161; Z. Landau, Władysław Zawadzki (1885-1939): Ekonomista-polityk-minister skarbu, 'Przegląd Historyczny' 1980, 4, pp. 753-771. 
politicians who made decisions on economic matters. The liberal and conservative economists went on the defensive i.a. because of changes in economic thinking on the global scale. A new axis of division emerged in the authoritarian camp: between the rightist and leftist radicals. One of the subjects of contention was ownership issues. Proponents of economic nationalism explicitly demanded that ownership transformations be carried out to strengthen the Polish holdings at the expense of the property held by foreign capital and national minorities. In contrast, the leftist radicals remained faithful to statism, i.e. they consistently supported the build-up of the state ownership sector. Ownership transformations were ignored, which were the main programmatic demand voiced by the Camp of National Unity (OZN).

Political programs and public policy on the foregoing three issues determined the range and scope of ownership transformations postulated or/and implemented by the Piłsudskites. Most political passions were inflamed by the issue of land reform, in which the Piłsudski camp was involved throughout the 1926-1939 period. After the May coup the Piłsudskite radicals expected an almost agrarian revolution concerning the form of land ownership and implementation of land reform for the peasants ${ }^{24}$, but the Commandant decided to hand over the conduct of the agrarian policy to the camp's conservatives and liberals (Witold Staniewicz, Leon Kozłowski, Leon Janta-Połczyński, Seweryn Ludkiewicz, Bronisław Nakoniecznikow-Klukowski, and Karol Niezabitowski), which meant the repudiation of radical projects and the adoption of the rule that the agrarian reform should not be a social task, i.e. it should not stem from the wish to quickly increase the holdings of the peasants or to protect landowners' holdings. The 'middle-of-the-road' policy was chosen: on the one hand, as the conservatives would have it, economic instruments were used to stabilize large-scale commercial farms, mainly those of landowners, on the other hand land ownership was spread to the rural peasantry in order to amplify their identification with the state and participation in the economic system as owners of workplaces. The spread of land ownership would, first of all, increase Poland's economic potential, not just reinforce the identification of peasants with the state. The land reform was therefore recognized as an economic undertaking, which should be carried out in a rational, fair, and honest way, in accordance with the financial capability of the state, and should be based on three premises.

Firstly, Piłsudski and his associates did not hope to reform the agrarian relations in the Polish countryside because they knew that

${ }^{24}$ See: W. Stpiczyński, My, piłsudczycy, 'Głos Prawdy' 7 November 1926, 166, p. 674. 
the land reserves were too small to satisfy social expectations, plans of experts, and political calculations (above all of peasant party activists) ${ }^{25}$. The Piłsudskites negatively assessed the economic conditions of the Polish peasantry, pointing out the low profitability of farms, overpopulation of the rural areas, or the negligible ability to accumulate capital in the rural economy ${ }^{26}$. For those reasons they did not overestimate the importance of the parceling out of land but they put emphasis on agrarian reform in the broad sense, in which parceling out would be accompanied by a comprehensive restructuring of the agrarian system. Secondly, the Piłsudski camp intended to solve the problem of ownership in agriculture in the long-term by means of intermediate measures: stable and longlasting economic growth, and industrialization and urbanization of the state. That is why the land reform was a political means used not so much to improve agrarian relations as to restructure the state's internal market and to support industrial development ${ }^{27}$. Thirdly, landowners' and peasant farms were expected to create complementary segments in agriculture, oriented towards cooperation rather than being the economic foundations of separatist group identities utilized by political parties. The Piłsudskites believed that the conditions for the land reform and its pace were intended to strengthen the unity of rural communities, regardless of their ethnic, social, occupational, and ownership diversification ${ }^{28}$. They rejected the view of parceling out as a factor of seeking peasant support for the Piłsudski camp at the expense of carrying out revolutionary changes in the social stratification of the rural population and through the redistribution of incomes by the state for the rural poor.

Under the conditions analyzed above, the land reform of 1926-1935 became, as the ruling camp wanted, a typical market transaction, spread out over time, without involving state coercion and expensive economic instruments. The state would be an intermediary between the landowners and the peasants, would financially support both sides, establish legal

${ }_{25}$ W. Roszkowski, Gospodarcza rola większej prywatnej własności ziemskiej w Polsce 1918 1939, Warszawa 1986, pp. 338-340.

26 A. Rose, Możliwości naprawy ustroju rolnego za pomoca ustawodawstwa, 'Przemysł i Handel' 15 December 1928, 51, p. 2078; W. Staniewicz, O program agrarny w Polsce i jego wykonanie: Mowy i przemówienia (1926-1928), Warszawa 1928, pp. 95, 115-116; idem, Przebudowa ustroju rolnego w Polsce: Przemówienie na Radzie Głównej Naprawy Ustroju Rolnego w Warszawie 31. stycznia - 1928 r., Warszawa 1928, p. 44; C. Klarner, Przemyst i handel w pierwszym dziesięcioleciu niepodległości Polski, Warszawa 1929, pp. 19-20.

27 W. Staniewicz, Przemówienie Ministra Reform Rolnych... na 14 posiedzeniu Sejmu w dn. 1 czerwca 1928 r., Warszawa 1928, p. 5.

${ }_{28}$ Idem, Przebudowa, p. 75; idem, Dwa lata dalszej pracy nad przebudowa ustroju rolnego w Polsce (1928-1929), Warszawa 1930, p. 88. 
norms, guard economic rationality, and stabilize the foundations of the economic system. Regarding the pace of changes, the following regularity can be observed: in favorable economic conditions the Piłsudskite politicians encouraged land reform whereas in recession they advocated the slowing-down of ownership transformations ${ }^{29}$. The latter attitude was the dominant one between 1929 and 1934/1935. The state in economic crisis lost its possibilities to protect the land reform, which is why the pace and scale of parceling out was reduced and subordinated to the state's agricultural policy. The next change was carried out after the mid-nineteen thirties when Piłsudski's successors began to abandon the previous rules of effecting ownership transformations in agriculture. The government circles (Minister of Agriculture and Agrarian Reforms Juliusz Poniatowski) began to speak of resuming the land reform to achieve temporary positive social effects by stopping the radicalization of the peasant masses in the country $^{30}$. The OZN declarations showed the land reform as an 'economic' measure to 'Polonize' economic life in the rural areas, which means that the beneficiaries of the resumed large-scale parceling out would be not only local peasants but also farmers of Polish ethnic group. The OZN agrarian theses urged support for 'the purchase of land by the local Polish population and the Polish settlers' ${ }^{31}$.

To the Piłsudski camp, the second most important ownership problem after the land reform was the takeover of private enterprises by the state (referred to as 'healing'). This practice was applied most strongly during the Great Depression and was motivated by extraordinary circumstances. In the second half of the 1930s there were heated debates among the Piłsudskites about the future status of the temporarily nationalized economic entities. The rightist radicals in the OZN announced that they would curb nationalization, start reprivatization, and protect private ownership through economic planning. They dissociated themselves from the state's domination of ownership. In contrast, the leftist radicals voiced different demands: they wanted to absolutely reject the negative attitude towards state ownership exhibited by the camp's liberals and conservatives, in favor of the plan of socializing jobs and business entities by dispossessing businessmen and landowners ${ }^{32}$.

${ }^{29}$ J. Ciepielewski, Polityka agrarna rzadu polskiego w latach 1929-1935, Warszawa 1968, pp. 57,84 .

30 M.M. Drozdowski, Polityka rolna rządu polskiego w latach 1936-39, 'Roczniki Dziejów Ruchu Ludowego' 1959, 1, pp. 96-106.

31 'popierać nabywanie ziemi przez miejscową ludność polską oraz przez polskich osadników'. AAN, OZN, ref. no. 26, p. 4.

32 For more on the socialization of private ownership see: J. Gołębiowski, Spór o etatyzm 
After the mid nineteen-thirties, the third ownership issue was politicized thanks to the Piłsudskites associated in the OZN. A proposal was put forward to 'Polonize' or 'nationalize' the economy, which meant the transfer of ownership according to the criterion of nationality. The OZN's policy documents emphasized two dimensions of Polonization of ownership. Firstly, the Poles would take over land and businesses previously owned by members of national minorities, mostly Jews and Germans, and by foreign capital. Secondly, the Polish state would make it difficult for Ukrainians and Belarusians to buy property, particularly land. The problem of Polonization was most pronounced in the Eastern and Western Borderlands ${ }^{33}$. The Piłsudski camp justified the Polonization measures by pointing out conflicts between the Polish state and the economic activities of members of national minorities and foreign economic entities. This new political project was a far-reaching change in the concepts and policy program for the Piłsudski camp's political thought, affecting even the ideological sphere because it was borrowed from the ideological activity of the national-democratic movement and clashed with the previous views on private ownership and independence of the economy from ideology.

Many documents proposed the four directions in which the measures of Polonization concerning ownership would be applied: 1) parceling from German and Jewish landed property; 2) apportioning of land to Polish settlers only; 3 ) halting the statutory takeover of Polish manor land by Ukrainian peasants; 4) handing over state businesses to Polish landowners in exchange for voluntary parceling out of manor land. Those directions of activities were expected to produce significant political effects: maintain Polish land holdings, increase the number of Polish-held businesses, privatize state-owned enterprises, and strengthen national ties between the peasants and landowners.

\section{CONCLUSIONS}

The Piłsudski camp which ruled Poland with absolute power between 1926 and 1939 was consistently in favor of private ownership,

wewnątrz obozu sanacyjnego w latach 1926-1939, Kraków 1978, pp. 65-70.

33 Uprzemystowienie Polski. Tezy Rady Naczelnej OZN uchwalone w dniach 28-29 lutego i 1 marca 1939 r., Warszawa 1939 p. 19; Deklaracja ideowo-polityczna szefa Obozu Zjednoczenia Narodowego Adama Koca i przemówienia przewodniczacego organizacji wiejskiej Obozu Zjednoczenia Narodowego Andrzeja Galicy, Warszawa 1937, pp. 12-14, 62-63; J. Piasecki, O gospodarce planowej, Warszawa 1938, pp. 5-6, 15-17. 
considering it the best form of ownership that would enhance Poland's potential and isolate the society from revolutionary attitudes that stemmed from intensified Bolshevik and Nazi propaganda and from the objective conditions existing in the Polish territories after the period of the Partitions. In matters of ownership, measures were taken in two directions: 1) depoliticization of problems of this kind; 2) decisionmaking in accordance with the 'middle-of-the-road' policy. Democratic parties were accused that by their activities they aggravated conflicts between different social groups: entrepreneurs vs. workers, landowners vs. peasants, rural inhabitants vs. townspeople. The Piłsudskites regarded this attitude as detrimental to the Polish state. They decided to abandon it effectively and consistently by carrying out ownership transformations based on economic criteria despite the fact that ownership transformations would be subordinated to the realization of political goals because the Piłsudskites believed that respecting canons of economic knowledge could contribute to the economic development of Poland.

When making the most important decisions concerning ownership issues, inspiration was sought from diverse theoretical schools of economics. First (before 1935), neoclassical liberal economics absolutely prevailed, amended by some solutions characteristic of the historical school. By combining the two approaches, the Piłsudski camp decided to pursue a 'middle-of-the-road' policy. With the growing danger of war and changes in the world economy after the Great Depression, economic nationalism was invoked but the canons of free market economy were not rejected. The globally dominant approach to the way out of the Great Depression was diagnosed fairly accurately. In their economic policies, the most important states in the contemporary world were guided above all by their own interest, giving up some of the solutions preferred by neoclassical liberal economics.

(translated by Jerzy Adamko)

\section{REFERENCES}

\section{Archival sources}

Archiwum Akt Nowych:

Bezpartyjny Blok Współpracy z Rządem. Sekretariat Generalny i Klub Parlamentarny w Warszawie, ref. no. 3.

Obóz Zjednoczenia Narodowego. Centrala w Warszawie, ref. no. 23, 26.

Prezydium Rady Ministrów w Warszawie, ref. no. 491. 


\section{Printed sources}

Bieżące zagadnienia polityki gospodarczej, vol. 1, Prace Komisji Opiniodawczej (przemysłowej) przy Prezesie Komitetu Ekonomicznego Ministrów, Warszawa 1927.

Bieżące zagadnienia polityki gospodarczej, vol. 4, Sprawozdanie z działalności Komisji Opiniodawczej Pracy przy Prezesie KEM za okres od dnia 17 XI 1926 r. do dnia 1 VII 1928 r., Warszawa 1928.

Deklaracja ideowo-polityczna szefa Obozu Zjednoczenia Narodowego Adama Koca i przemówienia przewodniczacego organizacji wiejskiej Obozu Zjednoczenia Narodowego Andrzeja Galicy, Warszawa 1937.

Inwestycje, kredyty, konsumpcja, eksport, żegluga: Obrady gospodarcze w dn. 22 i 23 lutego 1928, Warszawa 1928.

Jan Bobrzyński o kwestiach ustrojowych Drugiej Rzeczypospolitej, ed. E. Czapiewski, Warszawa 1998.

Klarner C., Drogi sanacji gospodarczej: Mowy ministra skarbu Czestawa Klarnera wygłoszone w sejmie w dniu 22 czerwca 1926 r., w senacie w dniu 30 czerwca 1926 r., Warszawa 1926.

Konfederacja Ludzi Pracy (Projekt), Warszawa 1924.

Krzyżanowski A., Polityka i gospodarstwo: Pisma pomniejsze oraz przemówienia 1920-1931, Kraków 1931.

Kwiatkowski E., Prawo zwycięstwa: Odczyt, wygłoszony w Poznaniu 26 maja r. 1929., Warszawa 1929.

Kwiatkowski E., Tendencje i postulaty rozwoju gospodarczego Polski: Referat, wygłoszony na kongresie Izb Przemystowo-Handlowych we Lwowie w dn. 3 września 1930 r., Warszawa 1930.

Materiały odnoszace się do działalności Rządu w czasie od 15 maja 1926 roku do 31 grudnia 1927: Sprawozdania ministerstw, Warszawa 1928.

Na froncie gospodarczym: W dziesiata rocznicę odzyskania niepodległości. 1918. 11 XI 1928, Warszawa 1928.

Narady gospodarcze Rzadu z Delegatami Izb Przemysłowo-Handlowych w dniu 7 i 8 października 1929 r., Warszawa 1929.

Staniewicz W., Dwa lata dalszej pracy nad przebudowa ustroju rolnego w Polsce (1928-1929), Warszawa 1930.

Staniewicz W., O program agrarny w Polsce i jego wykonanie: Mowy i przemówienia (19261928), Warszawa 1928.

Staniewicz W., Przebudowa ustroju rolnego w Polsce: Przemówienie na Radzie Głównej Naprawy Ustroju Rolnego w Warszawie 31. stycznia - 1928 r., Warszawa 1928.

Staniewicz W., Przemówienie Ministra Reform Rolnych... na 14 posiedzeniu Sejmu w dn. 1 czerwca 1928 r., Warszawa 1928.

Uprzemystowienie Polski. Tezy Rady Naczelnej OZN uchwalone w dniach 28-29 lutego i 1 marca 1939 r., Warszawa 1939.

Zagadnienie etatyzmu w Polsce: Stenogramy przemówień wygłoszonych na zebraniu u posła Janusza Radziwiłta w dniach 12 grudnia 1928 r. i 10 stycznia 1929 r., Warszawa 1929.

Zjazd działaczy gospodarczych $i$ społecznych zwołany przez BBWR. Warszawa, 18, 19 i $20 \mathrm{~V}$ 1933 r., Warszawa 1933.

\section{Press}

b.ł., Cuius regio - eius religio, 'Gazeta Polska' 29 October 1935, 300.

Doktryna i życie, 'Gazeta Polska' 22 April 1932, 111.

Fabierkiewicz W., Interwencjonizm państwowy, 'Gazeta Polska' 8 January 1932, 8.

Fabierkiewicz W., Wytyczne najbliższej przyszłości gospodarczej, ‘Gazeta Polska' 7 November 1931, 304.

Matuszewski I., Powszechna solidarność gospodarcza, 'Gazeta Polska' 28 August 1930, 236. 
Podwójny obowiązek, ‘Gazeta Polska' 14 April 1935, 104.

Polityka i ekonomia, 'Gazeta Polska' 29 December 1938, 356.

Poniatowski J., Polityka gospodarcza wobec koniunktury, 'Gospodarka Narodowa' 1931, 6.

Poniatowski J., Przeciać hamulce!, ‘Gazeta Narodowa' 1934, 12.

Postępy interwencjonizmu, 'Gazeta Polska' 1 August 1936, 213.

[Przemówienie Bogustawa Miedzińskiego w sejmowej komisji budżetowej z 8 II 1936 roku], ‘Gazeta Polska' 9 February 1936, 40.

Rose A., Możliwości naprawy ustroju rolnego za pomoca ustawodawstwa, 'Przemysł i Handel' 15 December 1928, 51.

Rose A., Na progu nowego roku, 'Gazeta Polska' 5 January 1932, 5.

Rose A., Wobec możliwości zmiany międzynarodowej polityki gospodarczej, 'Przemysł i Handel' 13 August 1932, 33.

Rose A., Wytyczne polityki europejskich państw rolniczych po 1932 r., 'Przemysł i Handel' 2 January 1932, 1.

Stpiczyński W., My, piłsudczycy, ‘Głos Prawdy’ 7 November 1926, 166.

Wytyczne programu gospodarczego rzadu: Mowa min. E. Kwiatkowskiego, wygłoszona w dn. 8 b.m., 'Dzień Polski' 11 May 1930, 127.

Zawadzki W.M., Zagadnienia państw rolnych Europy Środkowej $i$ Wschodniej, 'Przemysł i Handel' 27 August 1932, 35.

Zdarzenia i poglady, 'Gospodarka Narodowa' 1934, 3.

Zjazd Działaczy Gospodarczych i Społecznych, 'Gazeta Polska' 20 May 1933, 138.

\section{Studies}

Battaglia R., Dobrobyt społeczeństwa a wychowanie, Warszawa 1932.

Battaglia R., O programie gospodarczym Polski oraz o warunkach rozwoju poszczególnych gałęzi wytwórczości, Warszawa 1927.

Ciepielewski J., Polityka agrarna rzadu polskiego w latach 1929-1935, Warszawa 1968.

Drozdowski M.M., O myśli politycznej pitsudczyków polemicznie, 'Dzieje Najnowsze' 1969, 2.

Drozdowski M.M., Polityka rolna rzadu polskiego w latach 1936-39, ‘Roczniki Dziejów Ruchu Ludowego' 1959, 1.

Drozdowski M.M., Stefan Starzyński prezydent Warszawy, Warszawa 1980.

Dziewulski K., Spór o etatyzm. Dyskusja wokót sektora państwowego w Polsce międzywojennej 1919-1939, Warszawa 1981.

Faryś J., Myśl gospodarcza piłsudczyków 1926-1935, 'Szczecińskie Studia Historyczne' 1987, 1.

Gołębiowski J., Spór o etatyzm wewnatrz obozu sanacyjnego w latach 1926-1939, Kraków 1978.

Grzybowski K., Pięćdziesiąt lat 1918-1968, Kraków 1977.

Jabłonowski M., Z dziejów gospodarczych Polski lat 1918-1939, Warszawa 1992.

Klarner C., Przemyst $i$ handel w pierwszym dziesięcioleciu niepodległości Polski, Warszawa 1929.

Kofman J., Nacjonalizm gospodarczy - szansa czy bariera rozwoju: Przypadek Europy Środkowo-Wschodniej w okresie międzywojennym, Warszawa 1992.

Kowalik T., Historia ekonomii w Polsce 1864-1950, Wrocław-Warszawa-Kraków 1992.

Landau Z., Plan stabilizacji 1927-1930: Geneza, założenia, wyniki, Warszawa 1969.

Landau Z., Władystaw Zawadzki (1885-1939): Ekonomista - polityk-minister skarbu, 'Przegląd Historyczny' 1980, 4.

Leczyk M., Oblicze społeczno-polityczne Drugiej Rzeczypospoliteji, Warszawa 1988.

Lityńska A., Polska myśl ekonomiczna okresu międzywojennego, Kraków 1995.

Łapa M., Modernizacja państwa: Polska polityka gospodarcza 1926-1929, Łódź 2002.

Łapa M., Polityka stabilizacyjna w gospodarce polskiej po przewrocie majowym (15 May - 30 September 1926 r.)., 'Acta Universitatis Lodzensis. Folia Historica' 1998, 61. 
Majchrowski J.M., Silni - zwarci - gotowi: Myśl polityczna Obozu Zjednoczenia Narodowego, Warszawa 1985.

Makowski W., My i wy, Warszawa 1938.

Nowak M., Włudyka T., Rynek kredytowy w Drugiej Rzeczypospolitej, Kraków 1992.

Nowicki W., Polska myśl ekonomiczno-rolnicza w latach 1918-1939, in: Zarys polskiej myśli ekonomiczno-rolniczej do drugiej wojny światowej, ed. A. Żabko-Potopowicz, WrocławWarszawa-Kraków-Gdańsk 1973.

Okoniewska B., Gospodarka liberalna czy etatystyczna? Dyskusje o modelu gospodarczym Polski międzywojennej, 'Dzieje Najnowsze' 1993, 4.

Piasecki J., O gospodarce planowej, Warszawa 1938.

Pięć lat na froncie gospodarczym 1926-1931, Warszawa 1931.

Rakowski J., Ideologia gospodarcza epoki Józefa Piłsudskiego, ‘Niepodległość' 1948, 1.

Roszkowski W., Etatyzm przemysłowy w Polsce w latach kryzysu 1929-1935, 'Przegląd Historyczny' 1972, 1.

Roszkowski W., Gospodarcza rola większej prywatnej własności ziemskiej w Polsce 1918-1939, Warszawa 1986.

Rothschild J., Marshal Józef Piłsudski on State (Society Dialectics in Restored Interwar Poland, in: Poland between the Wars: 1918-1939: A collection of Papers and Discussions from the Conference "Poland between the Wars: 1918-1939" held in Bloomington, Indiana, February 21-23, 1985. A Publication of the Indiana University Polish Studies Center, Bloomington, ed. T. Wiles, Indiana 1989.

Zagóra-Jonszta U., Spory o model gospodarki Drugiej Rzeczypospolitej. (Problemy etatyzmu, planowania i kartelizacji), Katowice 1991.

\section{STRESZCZENIE}

Artykuł jest analizą poglądów politycznych na gospodarkę, decydujących o koncepcjach polityki gospodarczej, realizowanej w Polsce międzywojennej przez obóz piłsudczykowski - obóz autorytarny rządzący w tym państwie w latach 1926-1939. Dokonano analizy śladów i świadectw myśli politycznych, czyli źródeł wytworzonych przez polityków tej formacji politycznej oraz opisów podjętych wówczas decyzji. Przedmiotem zainteresowania były regulacje własnościowe, które miały nie tylko kontekst ekonomiczny, lecz przede wszystkim polityczny. Zbadano polityczne podstawy decyzji ekonomicznych podejmowanych przez dyktatora Józefa Piłsudskiego i jego współpracowników oraz następców, a także recepcję ówczesnych teorii ekonomicznych. W czasie przejęcia władzy zwolennicy nie uzasadniali zamachu stanu za pomocą argumentów ekonomicznych, mimo, iż sytuacja w gospodarce nosiła znamiona kryzysowej. Dopiero po zamachu opracowano postulowany ład własnościowy, w tym zakres i zasięg zmian w porządku gospodarczym.

Słowa kluczowe: autorytaryzm, myśl polityczna, gospodarka, system polityczny

\section{ABOUT THE AUTHOR}

Waldemar Paruch - Professor of Social Sciences in the field of political science and administration; the creator and the head of the Department of Methodology and Theory of Political Science and Administration; scientific specialty: methodology of the research in political science, theory of politics, political thought, political systems (authoritarianism), political parties (people's movement, Piłsudski camp, Law and Justice party), international 
relations (systems of security, foreign policy of the Republic of Poland, Central Europe). The author of 230 scientific publications (including 30 monographs), the editor-in-chief/ chairman of the scientific committees of some scientific journals of social sciences, among others - the editor-in-chief of 'Przegląd Sejmowy' ('Parliamentary Review'). He either is or has been: the advisor to the Marshall of the Sejm, the head of the Centre of the Strategic Analyses in the Chancellery of the Prime Minister in Poland, the member of the Council of the Foundation of CBOS (the Centre for Public Opinion Research), the expert of the Sejm, the main expert of the project 'Europe of the Carpathians', the analyst of public policies, the expert in the foreign policy. 